\title{
REINCARNATION OF THE PINAY SUBALTERN IN FOREIGN CINEMA
}

\author{
Taeyun Yu \\ University of the Philippines Film Institute \\ thisluckystrike@yahoo.com
}

\begin{abstract}
This paper explores the paradoxical condition of postcolonial practice in South Korea1 that is, in many ways, complicit with dominant discourses such as nationalism, patriarchy, and global capitalism. In such a condition, what remains obscured is the voice of women that behooves us to hypothesize that the image of diasporic Filipino women in Korean cinema is predetermined by such complicity and is ideologically reincarnated as the subaltern. By conflating two postcolonial concepts, hybridity (Bhabha) and subalternity (Spivak), the study inspects the hypothesis through an analysis of two films that depict diasporic Pinay images: as entertainer in Yangil Choi's All Under the Moon (1993) and as migrant wife in Han Lee's Wandeugi (a.k.a. Punch, 2011). In so doing, this paper revisits Spivak's ethical question "Can the subaltern speak?" in the postcolonial feminist context.
\end{abstract}

\section{Keywords}

postcolonialism; globalization; nationalism; hybridity; third space; subalternity

\section{About the Author}

Taeyun Yu is a Korean media and film scholar currently taking his graduate studies at the University of the Philippines Film Institute, where he also finished his B.A. in Film (cum laude). His thesis on sadomasochism in Korean cinema won the UPFI Special Award for Best Written Thesis. He was originally an exchange scholar from Hallym University in Korea. He has presented papers at several international conferences, including the Society of Cinema and Media Studies, and has been published in a number of journals, including Plaridel and ACMC Journal. 
IN TODAY'S INCREASINGLY POSTMODERN ERA, wherein the advancement of media technology facilitates the democratization of expression even for suppressed values and peripheral subjects, the answer to Gayatri Chakravorty Spivak's ethical question on the enunciation of the subaltern appears to be more attainable. However, this is not to say that Spivak's question will eventually reach a point of anachronism. Rather, it seems to be more relevant today inasmuch as certain discourses tend to silence the voice of the subaltern by mobilizing the media as a means of ideological dissemination.

Faced with the kind of globalization that has blurred the boundaries among nations and has bred hybridity among cultures in Korea, ${ }^{1}$ the postcolonial imperative has reared its head once again to seek the restoration of national subjectivity and identity. However, a number of opinions on the issue of postcolonial politics and its adverse ramifications on women's subjectivity tend to point out the conflicting interests of nation and women, urging the reconceptualization of nation and the incorporation of the feminist perspective in postcolonial discourse. In spite of the mutual political goal of postcolonial theory and feminist discourse in dismantling the grand narratives of colonial power and patriarchy, conflict emerges from the tendencies of postcolonialists to mobilize nationalist sentiment, another grand narrative whose "imagining is profoundly gendered" (Loomba, Colonialism/ Postcolonialism 180).

In the context of Korea, this is evinced in the fact that the gendered allegory of "the nation as woman" is deeply imbued within postcolonial discourse, wherein women are envisioned as representative of the nation within a set of ideal values (such as purity, morality, and self-sacrifice) imposed upon them; those who fail to conform are labeled the Other. Correspondingly, the postcolonial praxis in media tends to reflect on such rhetoric as its emphasis on nationalist discourse leads to its own pitfall, "signal[ing] the subordination, if not the demise of women's politics" (Radhakrishnan 77). To be more precise, nationalist discourse is most exclusively inscribed on the bodies of women, which in turn are articulated as double constraints: to allegorically represent the ideal nation and to politically represent cultural Otherness.

Meanwhile, globalization lies at the heart of debates over its impact on postcolonial regions-particularly on the global South. A number of critiques agree that the preoccupation of postcolonial studies with anti-essentialism and counter-grand narrativizing overlooks the base economic structure that entails geo-economic inequity in the here and now. This leaves postcolonial studies inadequate in challenging the onslaught of neoliberal globalization, which is now unfettered in reconfiguring the previous forms of domination and constructing the New World Order (cf. Hardt and Negri, "Symptoms of Passage" 137-59). Terms like Coca-colonization and Mcdonaldization may supplement its economic and sociopolitical cultural hegemony. 
However, such a post-Marxist approach may not fully grasp the impact of globalization on postcolonial politics in Korea. The country seems to have been able to mitigate its subjugation by negotiating the interplay between globalization and localization: globalization, in the sense that Korea has adopted the Western rhetoric of linear progress under its compressed version of modernization; ${ }^{2}$ and localization, in that the rhetoric of the nation-state is constantly summoned in calling for the sacrifice of people for the greater nation and the preservation of cultural values. As a result, Korea has become industrialized enough to be considered a candidate for First-World status (eventually attained via its membership in the Organization for Economic Cooperation and Development) and now joins the bandwagon of globalization, all the while engendering "cultural nationalism" (cf. Chungmoo Choi, "Aestheticism and Cultural Nationalism" 121-33).

This model of "glocalization" tips off Korea's ambiguous postcoloniality in its interaction with other nations that fall under the now-anomalous categorization of "Third World." Partha Chatterjee, in the particular instance of India, discerned the tendency of anticolonial nationalism to divide culture into the domains of the material/outer (representing technology, science, and economy) on the one hand and the spiritual/inner (representing the national/cultural identity) on the other; and he observes that "the greater the success in imitating Western skills in the material domain, therefore the greater the need to preserve the distinctness of one's spiritual culture" (6). Similarly, if the material sphere were achieved through participation in globalization, that of the spiritual might have become an aspiration in Korea, providing us with a clue as to why national cinema has emerged so prominently with the recognition of director Im Kwon-taek's work in the early ' 90 os when Korea's economic growth reached its peak (cf. Joo 68-72).

At this point, it would be prudent to ask how Third World women are situated and defined at the junction of globalization and in the ambivalent postcolonial discourse in Korea, especially considering that globalization sees the migration of Third World women ${ }^{3}$ as an affectively necessary form of labor acquisition. Numerous studies on the representation of female migrant characters in Korean media affirmed the recurrent image of the Orientalist stigma stamped upon them. Their perceived qualities as emotional, subservient, dependent, and thus feminine subjects become foils to Korean protagonists as rational, progressive, independent, and thus masculine, hence the subjectivity of Korea. In such a manner, the plethora of meanings and differences from their history and culture are completely occluded by the pre-given or constituted notion of the nation-people (cf. Cho; Hong; Yang).

In the cacophonous yet reconciliatory coevalness of various discourses in postcolonial Korea, what remains silenced would be the voice of the gendered subaltern that is doubly oppressed inside and out by masculinist nationalism on one hand and capital globalization on the other. Thus, taking a critical stance on the tripartite interplay of nationalism, (post)colonialism, and globalism, this paper revisits Spivak's ethical question "Can the subaltern speak?" in the postcolonial 
feminist context by looking at the imaging of migrant Filipino women in two samples of East Asian cinema: All Under the Moon (1993) and Wandeugi (a.k.a. Punch, 2011).

\section{Two Modes of Postcolonial Critique}

Two influential works that poignantly raise the discursive complicity mentioned earlier are from Bhabha and Spivak. The former aims to deconstruct colonial discourse "from outside" - the liminal/interstitial space rife with cultural hybridity. The latter positions herself "from within" to cut off the linkage between internal masculine discourse (i.e., nationalism and patriarchy in postcolonial regions) and the external global capitalism that forms a new form of global governance.

This study finds both strategies useful. First, Bhabha's hybridity can help unveil the postcolonial articulation (and its possible agency) codified in hybridized Korean culture. Conversely, Spivak's postcolonial feminist perspective is counterposed to Bhabha's by showing how his articulation results in further silencing the gendered subaltern. Second, the paradoxical situation of the postcolonial project in Korea stems from the discursive oscillation between the within/outside boundary as constitutive, so to speak, of coevalness between Subject/Other, inclusion/exclusion, hybridity/homogeneity, globality/locality, colonial/post(neo)colonial, postmodern/ (pre-)modern, and so forth. It would therefore be worth reviewing their key ideas before applying them to the Korean context.

As intimated so far, no postcolonial practice can be free of its ideological quagmire unless it rethinks the notion of nation and recognizes its heterogeneity and intersubjectivity. Despite the nation-state's ability to restore national subjectivity, it leaves behind those liminal/gendered subjects dispersed by the international division of labor because of its essentialist/totalist/masculinist actuations in defining its citizens. Seizing upon the problematic rhetoric of "nationness," Homi K. Bhabha proposes the concept of "DissemiNation" in Nation and Narration by reconfiguring nation as narrative in order to show the nation's conceptual ambivalence and its conflicting temporalities. Bhabha asks, "How do we plot the narrative of the nation that must mediate between the teleology of progress tipping over into the 'timeless' discourse of irrationality?" (294). Simply put, such an enigmatic question insinuates the untranslatability of immiscible times ${ }^{4}$ and the tension caused by the conflict between: "the pedagogical function" of a nation that imposes homogeneous, progressive, holistic, and historically linear temporality on its people; and their everyday lives (what he calls "performativity"), which is rife with multiple temporalities that cannot be fully translated/understood with its imposed temporality (Bhabha, Nation and Narration 139-70). For him, the tension of "narrative authority between the pedagogical and the performative" (148) results in a split subjectivity and eventually opens up a fissure-the cultural liminality of the national narrative. 
With the conception of split subjectivity and cultural liminality, Bhabha proposes a "third space" that is no longer bound by the nation on the grounds of cultural and ethnic origin with a shared history. Rather, it comprises hybridized cultures and identities whose agency eventually serves as a counter-narrative against not only colonial discourse but also the authority of nation. To illustrate the subversive politics of the third space, Bhabha directs his attention to the ambivalence of colonial discourse, which enables the colonized Others to resist the dominance of power through performative "mimicry:"

Mimicry is, thus, the sign of a double articulation; a complex strategy of reform, regulation, and discipline, which "appropriates" the Other as it visualizes power. Mimicry is also the sign of the inappropriate, however, a difference or recalcitrance which coheres the dominant strategic function of colonial power, intensifies surveillance, and poses an immanent threat to both "normalized" knowledges and disciplinary powers. (Nation and Narration 86)

It is a sign of what is "appropriated" that compels the colonized subject to follow the constitutive traits of the colonizing power, but the same sign becomes "inappropriate" due to the colonizers' fear-a fear that compels the colonizer to restrain the colonized subjects from becoming their exact replica, in order to maintain their seemingly essential cultural differences. A double vision occurs in disclosing the ambivalence of colonial discourse and disrupting its authority through "mimicry/mockery" dynamics, which is "exactly like the technique of camouflage practiced in human warfare" (Nation and Narration 121). Similarly, hybridity is also a textual camouflage that emerges from the translation of cultural differences. In Bhabha's terms, it is "how newness enters the world" (cf. 212-35) where multiple identities and cultures proliferate while authority and its discursive language of power are rearticulated, retranslated, and thus decentered in the colonial context.

Likewise, in his mode of reading, any sort of ambivalence (space, time, nation, and power) fosters the agency of the third space where "the very practice of domination by the language of the master becomes hybrid-neither the one thing nor the other" (Bhabha, Location of Culture 33). Furthermore, nationalist politics based on cultural and ethnical difference is rendered moot in the wake of the interstices that overlap the domains of difference and displace "the polarity of a prefigurative self-generating nation" (Location of Culture 148).

\section{Hybridity's Critical Problems}

It is, however, this notion of hybridity that poses critical problems in spite of its usefulness in understanding the ambivalence of power dynamics and the heterogeneous coexistences of diverse cultures. On one hand, hybridity itself may enact a type of colonial chicanery to legitimize its power. Such criticism is 
partly caused by Bhabha's tendency to disavow an overtly Marxist perspective, overlooking the material conditions of the postcolonial region, and his reappraisal of Said's pessimistic view on the absence of agency of the colonized in the latter's Orientalism, resulting in his over-valuation of agency. Reflecting upon its weakness, JanMohamed argues that Bhabha's notion of hybridity can only be sustained by "circumvent[ing] entirely the dense history of the material conflict between Europeans and natives and ... focus[ing] on colonial discourse as if it existed in a vacuum" (JanMohamed 60-61). Indeed, such biting criticism seems tenable if one questions whether Bhabha's psychoanalytically informed model of agency (of the hybridized/colonized) can be actualized in the conscious practice of resistance when, in fact, his cultural hybridity is overtly used today by multinational enterprises and so-called privileged states in the name of multiculturalism to draw out the general consent of their capitalist interests.

On the other hand, due to the preoccupation with deconstructing/displacing the nation, race, and master-slave power relation as linked to masculine psychoanalysisnamely, those of Freud and Lacan - the politics of gender is once again left behind, thus foregrounding the masculine nature in postcolonial discourse. Correspondingly, postcolonial feminists point out that the voice of women still lies in shadow as "the colonial subject [in postcolonial studies] is remarkably free of gender, class, caste, or other distinctions" (Loomba, "Overworlding” 316). If Bhabha's hybridity speaks of resistance and emancipation from the "in-betweenness" of cultures, it is his hybridity that subsumes the Third World women who are staggering between the twin poles of (post)colonial and patriarchal reality.

Recognizing the predicament and the double oppression of women in its wake, Spivak explicates the complicity of Western intellectual production in global capitalist interest. For Spivak, the international division of labor is no different from an imperialist "worlding of the world" (Spivak, The Postcolonial Critic 1) ${ }^{5}$ because it constructs a new form of governance operating under the logic of capital and profit; that is, it geo-economically colonizes the Third World once again. This point is made more explicit in Spivak's adoption of the Gramscian term "subaltern," referring to the gendered oppressed whose bodies are doubly split as cheap laborers dispersed by global capitalism and as bearers carrying the burden of patriarchy (cf. Spivak, "Woman in Difference" 96-120).

In her influential study "Can the Subaltern Speak?" Spivak criticizes the epistemic violence of radical intellectuals (not necessarily from the First World) for representing the subaltern's voice via the intellectuals' cultural and ideological filtering. From her point of view, the act of "speaking on/for/about" the subaltern is a mere repetition of the subject-constitution of the colonized by her master, who speaks on behalf of his subject as a display of benevolence (i.e., the white man's burden ${ }^{6}$ ). Such a paradox, she holds, is mainly due to what she calls the mechanics of the "itinerary of silencing" (The Postcolonial Critic 31), which refers to the production of the subaltern as "a seemingly freely speaking subject/agent 
in the discourses of the dominant order" (Schwarz and Ray 452), a limitation that can be perceived even in the output of several progressive "radicals"-for instance, Michel Foucault and Gilles Deleuze, due to their "utopian" conception of Others (cf. Spivak, "Can the Subaltern Speak?" 66-8o).

At the same time, the tendency of intellectuals to use Western hegemonic vocabulary is incorporated even in postcolonial studies to articulate the voice of the subaltern, resulting only in effacing their voice and shutting them off from postcolonial or feminist scrutiny. ${ }^{7}$ Thence, by surmising that the subaltern cannot speak for herself, Spivak encourages intellectuals to unlearn their privileged position- "postcolonial intellectuals learn that their privilege is their loss" (Spivak, "Can the Subaltern Speak?" 82) - and learn how to "speak to" instead in order to "speak as/for" rather than "on behalf of" the subaltern.

\section{Determining the Subaltern}

What does it mean then to "speak to," and, more importantly, who are the subalterns in Korean cinema? Are they both subaltern and hybrid? If so, would they have agency to speak no matter how liminal they are? These are the questions that must be dealt with before the study deploys these two critical theories inasmuch as they seem to be incompatible with each other due to their contesting conclusions regarding the degree of agency.

Regarding the first question on who is to "speak to" the subaltern, I would venture to propose the filmmaker's positionality. Needless to say, in filmmaking, the immense duty of speaking to the subaltern is given to the director, who may or may not accurately represent the subaltern, entirely depending on her or his subject-position. This is one crucial question that the present study aims to investigate in analyzing the two films that narrate the interaction of diasporic Filipino women with Koreans. All Under the Moon, which was directed in 1993 by a Korean diasporic filmmaker in Japan, Yangil Choi, is a Tokyo-set romantic narrative between a Filipina sex worker (played by Ruby Moreno) and a Korean émigré. Wandeugi (a.k.a. Punch), a recent Korean hit film, depicts a multicultural family, where Filipino actress Jasmine Lee plays the role of the migrant wife. By adopting the auteur structuralist approach, ${ }^{8}$ I hope to conceptually resituate the films as cultural products that would reveal not only their respective directors' subject-positions but also the cultural standing of the films in terms of postcolonial and identity politics in Korea.

Concomitant with defining the subaltern in Korean cinema is the questioning of my own positionality as a male Korean scholar residing in the Philippines. The very notion of subalternity itself rests on the assertion that it is nearly impossible to speak for the subaltern. This means that the idea of speaking about the Filipina as the subaltern in Korean cinema is ironic no matter how liminally I am located in the interstices between Korean and Philippine culture. With this acknowledgment, 
however, I dissent with Spivak's deterministic point of view regarding the agency of the subaltern for the reason that Spivak, as a subaltern subject (regardless of her degree of alterity), is nevertheless invested in speaking for herself in imperialist territory. To put it bluntly, the complete lack of agency in her argument may have been, to some extent, predetermined as Spivak's criticism against the epistemic violence of intellectuals can only be ironically validated with the pessimistic premise that "the subaltern[s] cannot speak for [themselves]." In this way, their hybridity as a possible source of agency is, more or less, underscored.

Furthermore, if one were to follow Spivak's categorization of the subaltern, then Korean women are placed under the influence of the category inasmuch as they are doubly oppressed by both (post)colonial discourse and nationalist patriarchal ideologies. Thus, the present study sees both Korean women and Filipina characters in Korean cinema as subaltern subjects who share the characteristics of hybridity as a result of globalization. If Bhabha's hybridity is poised against Spivak's subalternity in theory, it will be this new hybridized subalternity in reality that this study considers.

It is from this position that I wish to look at hybridized subaltern politicsthe politics of the repressed that may unveil the possibilities and limitations of postcolonial discourse. To facilitate this activity, the study will first interrogate the way in which the image of the Filipina immigrant wife is constructed in Wandeugi by inspecting the ambivalent relationship between multiculturalism and nationalism, both of which are incorporated in postcolonial discourse in Korea. Then, the discussion will shift to the more subversive nature of postcolonial politics by reading the earlier filmic account of All Under the Moon. This will focus on how postcolonial discourse is inscribed in filmic visuals and narratives as a way of resisting the colonial hegemonic power; how the degree of alterity (mainly from the geo-economic stratification of class and gender positions between Korean and Filipina subalterns) defines the types of hybridized subalternity; and how their dialectical relationship forms a subjectivity that may set possible further directions for postcolonial practice.

Finally, it must be acknowledged that this paper is and will always be impartial in speaking to the subaltern "as or for" them due to its discursive nature of inviting the contestation of the various positionalities of the film directors, the present author, and the readers. However, it is the hope of this study to establish an atmosphere that facilitates the enunciation of the subaltern by revealing the paradoxical condition of postcoloniality, which is, in many ways, complicit with dominant discourses such as nationalism, patriarchy, and global capitalism. 


\section{The Myth of Multiculturalism Vis-à-vis the Migrant Filipino Wife}

There is something wrong with the concept of "multiculturalism" in Korea. When I heard of it, there was a sense of relief as I thought that we are finally recognized,... but then it seems to be another labeling that is used to distinguish "us" from the people.

(Except from an interview with Jasmine Lee) ${ }^{9}$

Earlier appearances of Filipinos in Korean cinema have been mainly incidental: usually as migrant workers, wives, or even gangsters. However, with the increase of foreigners living in Korea (exceeding one million since the millennium, which is enough to open up the interstices of transnational/ethnic/cultural hybridity), local films began to acknowledge their presence and, thus, raise multicultural awareness as evidenced by Han Lee's blockbuster release Wandeugi in 2011. Based on a popular source novel, Wandeugi depicts the coming-of-age story of eighteen-yearold Wan-deuk, who lives with his diminutive hunchback father and his mentally challenged uncle, Min-gu. Though his high-school performance is as poor as his poverty-stricken circumstances, he exhibits unusual protectiveness toward his father and uncle, who are often derided and discriminated against by society due to their physical handicaps. Unfortunately, his eccentric teacher Dongju, who is also a church minister, keeps singling him out in and outside the classroom and even at home as he lives across the street. The protagonist prays for his teacher's demise in church only to wind up being mentored by him. One day, his teacher, who helps illegal immigrants through his church ministry, finds out that Wan-deuk's mother (Jasmine Lee) is still alive and is Filipino. The rest of the plot focuses on the process of acceptance between the estranged mother and son.

If we look at the narrative briefly suggested above from the syntagmatic point of view (analogous to the director's own subjective position that is aligned with the perspective of the privileged majority), the film seems to make minority citizens (mentally challenged uncle, hunchback father, the poor, and, especially, the Filipino mother as representative of the immigrant subaltern group in Korea) visible once again to Korean audiences. This urges the audiences to recognize their ghostly presence and their hardship in dealing with their host society. However, if we look at the same narrative in terms of the paradigmatic viewpoint (analogous to that of Spivak, requiring the extraction of the narrative of the Filipino immigrant wife from the syntagmatic story), the implication would contradict the utopian vision of a multicultural society from the film's resolution, wherein the Filipina immigrant wife becomes a speaking subject, recognized and accepted in Korean culture.

The logical question "Who is this subaltern speaking?" then follows. If she can speak, is it her own voice that she enunciates or is it the voice of the dictating discourse as hidden actor? In the present reading of Wandeugi, I will 
seek to explicate how the Pinay [colloquial term for Filipina] subaltern's body is remapped, reterritorialized, and reborn by looking at the segmented narrative that can be mapped unto the character's own three-act structure: atonement for her abandonment of her Korean family, desire to return to her family, and successful reunion with the family.

The first act of this reconfigured narrative structure introduces the Filipino character and her remorse about abandoning her family. In this initial segment, her sense of guilt and Otherness creates the first emotional signifier, "passivity," wherein a sense of belittlement and faceless subjectivity is relentlessly built up through the use of a series of images (Figure 1). Accordingly, she is constantly positioned in the background, framed within low-angle compositions, and sutured through the eyes of the spectator as exercised by the POV device. Such passivity is further maximized by her subservient manner toward the other characters (including her son with whom she uses Korean-language honorifics) and by her helplessness as she can only meet her child with the aid of Wandeuk's teacher Dongju.
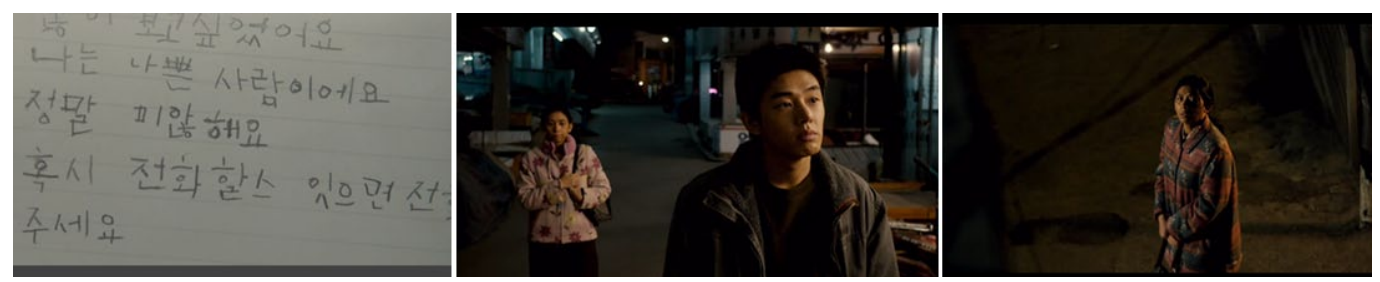

Fig. 1: Left: Diegetic use of the letter indicating awkward spelling emphasizing the mother's linguistic inadequacies, Middle: Placement in the background to emphasize her passivity. Right: Use of a high angle to indicate her helplessness and low self-esteem.

Furthermore, the third eye omnipresent in the film reinforces the emotional signifiers attached to her by marking her Otherness. In Souls of Black Folk, W. E. B. Du Bois elucidates the "double-consciousness" of African Americans as their subjectivity is formed and split through "the eyes of others, of measuring one's soul by the tape of a world that looks on in amused contempt and pity" (2). Similarly, it is the diegetic characters and the Korean audience alike who constantly signal her difference as Other from "over there," a bitter gaze that reinforces her passivity whenever she encounters it. For instance, when the protagonist Wan-deuk insists on buying her a new pair of shoes, the female shop lady keeps asking the protagonist about their relationship until he finally identifies her as his mother. The following point-of-view shot captures the lady's puzzled and speechless look. In this regard, it would be worthwhile to unveil the underlying discourse that predetermines the mother's passivity. 
In the context of globalization and the present-day multicultural era, nationalist discourse in Korea seems to be far more ambivalent as it manifests a double-faced politics, that is, postcolonial but Orientalist and multicultural but homogeneous. Marked by different historical and political forces of colonization, the formation of the Korean nation was a result of the trauma of de-territorialization from colonial discourse and legacies, and of the re-territorialization of its people into the native ideal of "homogeneous and empty time" (Anderson 24). This indicates the confluence between postcolonial and national discourses as a way of recovering from the traumatic colonial experience and of initiating national developmental projects. Ironically, through the modernization that positions Korea as the one of the most affluent nations in Asia today, Korean society internalizes rather than problematizes the Western blueprint in the name of progress and reason, which only results in a willing subjugation to the master narrative. As a result, an Orientalizing consciousness prevails in the mind of Koreans, which will be further discussed in the succeeding reading of All Under the Moon.

One glaring example that substantiates such a self-contradictory nationalistyet-Orientalizing discourse can be found in the sequence where the title character is dismayed by the news from his teacher and reveals his sense of shame through his voice-over monologue, "I have a mother who is not Korean but a Filipino." What triggers such a response from the protagonist, facilitating the identification of Korean audiences who can easily share and understand his feeling, is a deeply ambivalent nationalist discourse that is embedded in the consciousness of its primary spectators. On a connotative level, it is the ambivalent nationalist discourse in Korea that predetermines the initial signifier of the subaltern as a way of maintaining the homogeneous and empty time by excluding her as "Other," while her over-emphasized passivity, coupled with her helpless, sympathetic, and subservient manner, foregrounds the melodramatic essence that draws empathy from audiences.

The second act involves the mother's desire to return to her family, which takes audiences on a roller-coaster fluctuation from estrangement to embracement and from conflict to climax because of the strong albeit initially repressed emotions between mother and son. In this stage, her emotional side is expressed through her "self-effacement" signifier as her absence becomes presence through explanatory inserts such as her letter and the dinner box (Figure 2). In this regard, her "nowhere" presence becomes "now-here," or what Deleuze calls the out-of-field "disturbing presence' [that] cannot even be said to exist, but rather, to 'insist' or 'subsist,' a more radical elsewhere, outside homogeneous space and time" (17). As a result, her desire to nurture her son once again is strongly felt by audiences as they sympathize with the protagonist even though her "presence" had previously been only in the form of absence. This helps foreshadow the pathos induced out of both her son and the audiences. 


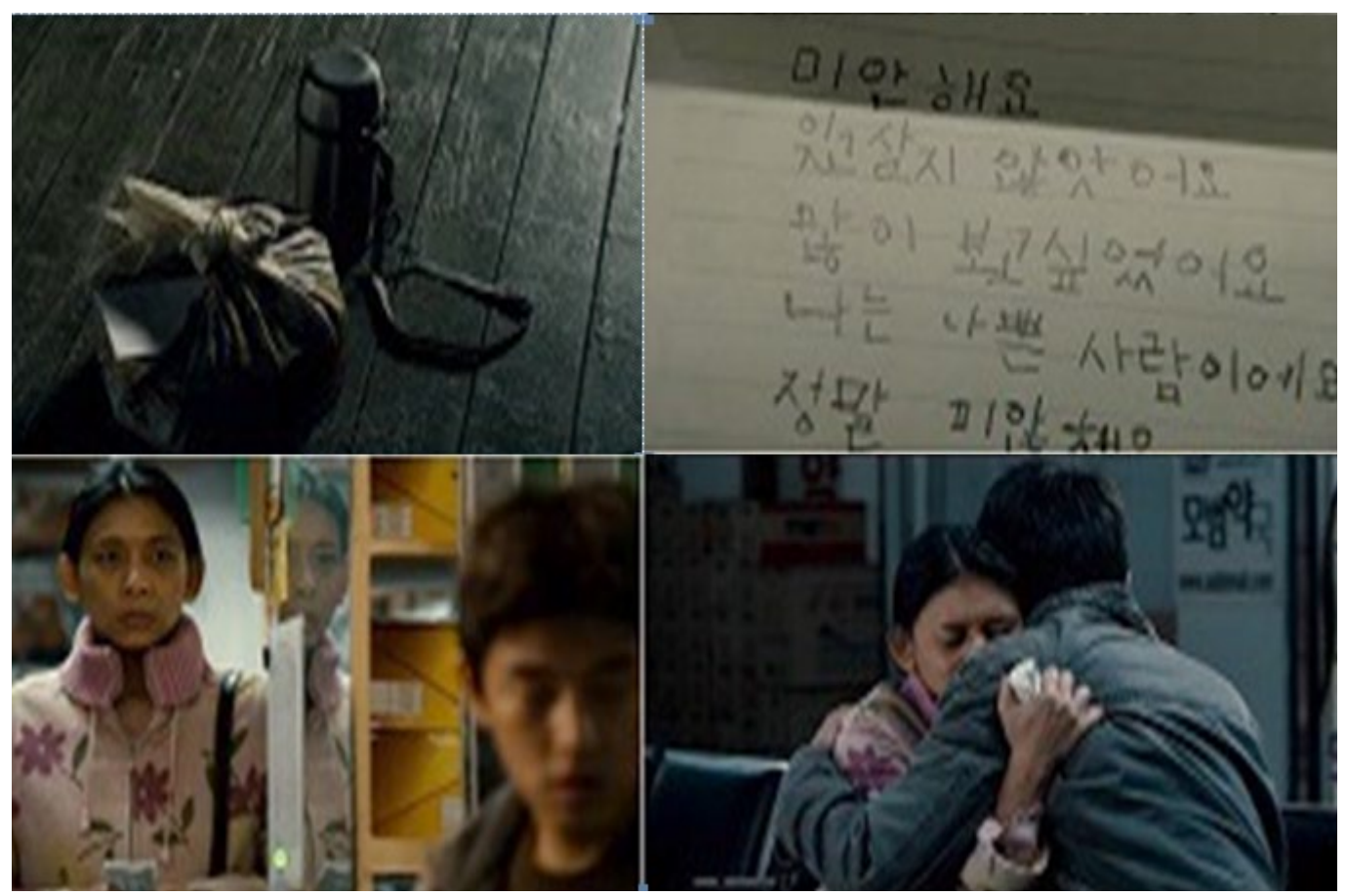

Fig. 2: Upper left and right: Explanatory inserts of dinner and letter stating "I'm sorry. I never stopped thinking of you. I missed you so much. I am a bad mother. I am really sorry" (translation by the present author). Lower left: Footwear store where she is first called "mother" by her son. Lower right: Climax of embracement where the contained emotion is released.

Soon, as mandated by melodramatic convention, her nurturing signifier melts the emotional glacier between her and the protagonist. The latter calls her "mother" for the first time in the footwear store where he insists on buying her a pair of new shoes. The following static long take captures the subtle emotional rapture that she must carefully contain until she reaches the climax, the central tearjerker scene in the bus station where she first utters her son's name to his face and finally hugs him and cries over his shoulder. The scene incites a cathartic as well as dramaturgical release (Figure 2).

At its connotative level, the emotional signifiers inscribed on her body reveal a patriarchal imposition that includes her as the apotheosis of [ideal Korean] femininity, an allegorical representation of the ideal nation. From a feminist perspective, if one were to look at Korean history, nationalist/postcolonial politics have ironically reinforced the patriarchal structure by envisioning women as the allegory of nation. For instance, the postcolonial attempt to find the nation's 
subjectivity after the traumatic colonial experience under the Japanese regime was done via the "re-stressed identification of woman" (Lee 259) where, as in Western culture, the image of the nation was envisioned as feminine. In effect, the nation as woman was collectively imagined as essentially vulnerable to the threat of violence, which serves as a justification for men to be active agents for the nation itself as opposed to women who, as passive beings, were properties of the nation's representatives.

Similarly, in the context of today's post-IMF era where an ever-increasing concern on the loss of masculinity is apparent in Korea, ${ }^{10}$ it is the foreign woman who is allegorized as nation as a way of restoring the phallic order by inscribing patriarchal imperatives upon the body of the subaltern as passive and self-effacing. This reincarnates the foreign woman as the apotheosis of traditional femininity: willing to be silent, self-effacing, and even self-sacrificing for the sake of "motherhood." This signifier of the good mother in the narrative resolution marks the peak of her development, where she returns to the waiting arms of the nuclear family as its long-missing nurturer. The embracement of the family and nation is made possible by her effective fulfillment of the nationalist and patriarchal signifiers of "passivity," "self-effacement," and "maternity" through the affective development of her own heretofore hidden three-act narrative structure. This grants redemption to the entire cast and, by extension, the spectators-the successful reunion with her estranged family and her (and their) metaphorical acceptance to the nation.

The foregoing film analysis has endeavored to connect the mother's emotional signifiers to their hidden hegemonic discourses. The illustrated image-construction of the Pinay subaltern reveals discursive ambivalence in two opposing folds: nationalistic exclusion as Other and patriarchal inclusion as the apotheosis of and the reward for "good" Korean femininity. This means that the image of the Filipino woman in Wandeugi is co-opted and co-inscribed by nationalist discourse in conjunction with capitalist logic as exercised by commercial cinema and patriarchal ideology, all of which conspire to create the ideologically fetishized image of the subaltern. The ambiguous representation of the subaltern's image in media further reflects the discriminatory inclusionary and exclusionary policies of social integration under the name of multiculturalism, thus contrasting the film's utopic version of multiculturalism with the containment proffered in its closure. This is very much a "true" case in real life as the actress Jasmine Lee, who was an immigrant wife (later widow) and was subsequently elected as the first foreign-born member of the National Assembly, pointed out the limitations of multiculturalism in Korea during an interview.

At this point, it would be timely to return to the question Spivak raised: Can the subaltern speak? The answer ought to be qualified in terms of how her voice is retranslated, rearticulated, and thus doubly effaced by the intellectual with the ideological and cultural filtering in Korea, in effect reconfiguring the gap between home and nation (or, put another way, reincarnating Douloti the Bountiful-cf. 
Spivak, "Woman in Difference"). This conclusion brings us to the next inquiry on how to "speak to" the subaltern in ways that enable cinema to represent her true meaning/subjectivity (rather than dismissing this distinguishing element as mere signifier of various ideological discourses) and whose "speaking" may not only work counter-hegemonically against colonial authority but also transcend the impasse in postcolonial discourse, This urgent question may be uncovered in the following reading of All Under the Moon.

\section{Politics of Third Space \& Orientalist Consciousness}

Japan experienced an unprecedented cultural and ethnic influx from neighboring countries. This influx was triggered by its rapid post-war economic growth up to the early 1990 on and became the harbinger of the transformation of the purportedly closed country into a multi-ethnic/cultural society. However, similar to other immigration countries such as Korea, the transition was far from smooth as reflected in the society's tendency to demarcate immigrants in Japan as Others. Although the majority of immigrants came from Korea and China, followed by other South East Asian countries (Philippines, Thailand, and other nationals), the strong fascination of the Japanese public imagination with the immigrants and the disturbance they exert on the public imagination have been demonstrated most strikingly in the pervasive image of the Japayuki. Coined by the Japanese filmmaker Yamatani Tetsuo, who denounced Pinays as "a convenient public toilet" as "a reality of Southeast Asian women in Japan," the problematic term Japayuki homogenizes Pinays as "immoral" Others with their eroticized body fit for prostitution, thereby indirectly demonstrating the citizens' ambivalence toward their country's thenrapid rate of transformation (cf. Suzuki 68).

Given this socio-cultural context, Korean diasporic filmmaker Yangil Choi (Yôichi Sai in Japanese nomenclature) made a semi-autobiographical film titled All Under the Moon ${ }^{11}$ where the plight of the members of a marginalized multi-ethnic group is depicted in a gently farcical and humorous manner. Despite its unpopular thematic concern with the immigrant's plight as well as its technical shortcomings, the film immediately became a huge succès de scandale in Japan and was recognized as one of the best films of all time in the renowned Japanese film magazine Kinema Junpo. At best, the film won major prizes in several festival and critics' competitions, including five separate trophies for its Filipina performer Ruby Moreno (cf. IMDB. com listing). At worst, Moreno was inaccurately and slanderously declared "the Star of Japayuki" ("Hito" 3), as the embodiment of eroticized Pinays in the public imagination.

The film's success may have been due not to its plot-a quotidian slice-of-life of a number of Asian minority groups and a whirlwind romance between Pinay entertainer Connie (Ruby Moreno) and Korean émigré Tadao (Gorô Kishitani) but rather in its radical and political stances. It is radical in the sense that the image 
of the diegetic Zainichi (the resident Korean population in Japan) characters in the film has a striking contrast with previous representations of Korean residents in Japan inasmuch as contemporary Zainichi filmmakers depicted them in ways to raise awareness of the social injustice and racism embedded in Japanese culture (cf. Yeongshim Kim).

Instead, the film presents a tragicomic fresco of the Asian immigrant experience in Tokyo in a nonchalant and nuanced manner to attenuate its thematic antagonism. In this way, the film offers the Japanese mainstream audience an armchair position without demanding compulsory moral guilt while still bidding for the immigrant subjects' social recognition. However, the film is unavoidably political as the director exposes how Korean Japanese, who have experienced discrimination, replicate a recognizably similar imperialist episteme against other subclasses such as Filipinos. As such, the film analysis that I will attempt will focus mainly on postcolonial politics with regard to hybridity to see how it demystifies Japan's homogeneity and to further discuss its limitation and possibility by identifying various types of hybridized subalternity.

With cheerful background music, the film establishes its visual thematic concern by monotonously presenting a taxi company wherein all the wacky and marginalized characters - the Korean owner of the company obsessed with profiting from a golfcourse project; a Japanese driver with signs of schizophrenia; a divorced husband raising his baby on his own; an illegal Iranian resident working as garage mechanic; and the protagonist-interact with one another and dawdle around (Figure 3). In this way, the opening sequence clearly establishes the third space as a sort of diasporic miniature and insinuates its political direction: a farcical resistance of the subaltern subjects. Henceforth, audiences are invited to witness kaleidoscopic vistas of hybridized spaces: the Korean-style house of the protagonist's mother, the karaoke club (where Pinay hostesses serve their Japanese patrons), the Catholic church (where the Pinay workers and the Filipino priest speak in Tagalog), and a wedding sequence (where North and South Korean immigrants in their traditional national costume sing a Korean folk song, "Arirang"). In short, these spatial visualizations throughout the film operate as ruptures in homogeneous Japanese culture.
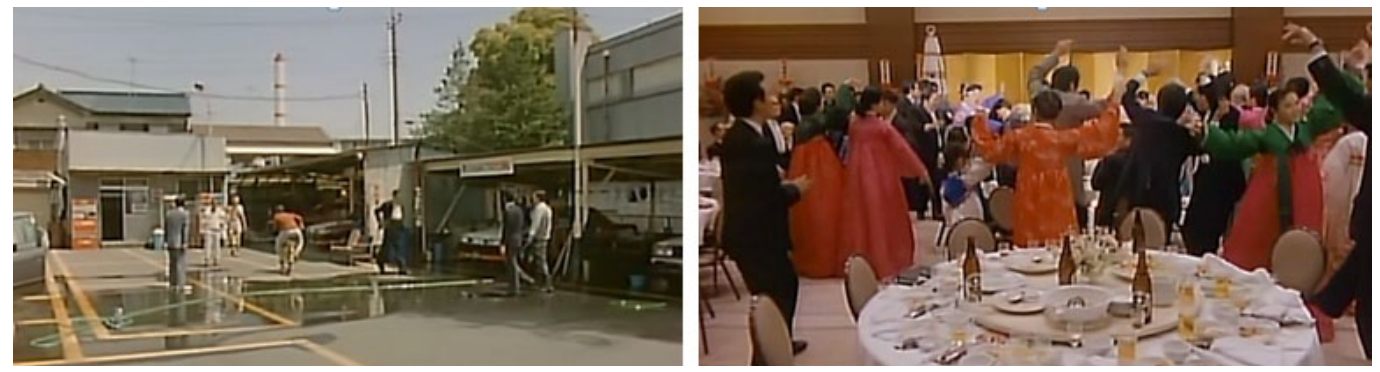

Fig. 3: Left: Opening sequence with a long view of a taxi company's parking area. Right: wedding scene wherein guests in traditional Korean costumes sing "Arirang" while dancing together. 
Spatial fissure is further extended to temporality as reified in the form of nostalgia in the film. Originally intended to prescribe "pathological sadness among exiles that was caused by their desire to go return home" (Lim 158), nostalgia was initially conceptualized along a spatial dimension. Eventually it extended its realm to that of temporality as the term is now often used to describe "a desire to return to a lost time" (ibid.). Based on the spatiotemporal nature of the trait, Lim points out that nostalgia, which literally means bringing the past back to the present, is both "retrospective" and "redemptive," thus allowing heterogeneous time or other temporalities to coexist with linear modern homogeneous time. Seemingly in line with her temporal critique, the various audiovisual cues in the All Under the Moon's mise-en-scène (i.e., traditional Korean costumes, furniture, and especially the Korean folk song "Arirang," which symbolizes the unified Korean nation before it was occupied, modernized, and divided by competing global interests, starting with Japan) all seem to evoke a sense of nostalgia to the eyes and ears of any insider who happens to be privy to their textual encryption. This further allows cultural insiders to decode the message in a way that general audiences could not. For instance, a sense of nostalgia can occur in the scene wherein the protagonist and his mother reminisce about the family they left behind in North Korea while packing an international parcel with food, clothes, and money to be sent to their homeland. For those insider spectators, it is not material values that they are packing but rather nostalgic memory and the desire to be remembered and to cross the boundary between the formerly colonial host country and the formerly colonized homeland that now exists only in an imagined form. Not only does this reminiscence reflect their desire to return through the spatial dimension but it also acts as a temporal synecdoche that, in turn, allows colonized or lost time to gnaw into the imperialist linear present.

As suggested, the film's spatial-temporal palimpsest of Japan manifests a specific postcolonial ambience by opening up an in-betweenness/third space. However, it is unclear how Bhabha's concept of hybridity in the third space can resist against the language and structure of colonial power until one considers three of its implications on identity constitution, specifically use of language, identity politics, and translation. To begin with, the film insists on the cacophonous use of the languages (Korean, Japanese, Filipino, English, and Iranian) spoken by the different ethnic and cultural characters, even with their respective dialects (e.g., Connie speaking in Osaka dialect in Tokyo, adding another layer to her diasporaness), and subtitles in Korean and Japanese provided in the Korean DVD copy. Given what Benedict Anderson has called "print capitalism," the use of vernacular language instead of Latin script in print media plays an incipient role in forming the idea of nation among readers because they are able to understand one another by means of their own dialects, thus creating ethnic affinity among them. Conversely, such hybridized multilinguality in the film works to desynchronize the cultural/linguistic structure if a homogeneous culture is driven by the hegemony of a synchronous 
language, ultimately undermining the very notion of a homogeneous national identity.

The second implication is germane to the acceptance of third identity by emancipating the subject from binary distinctions such as the us/them divide. If one were to ponder upon its relation to nation formation, identity itself may be regarded as the consequence of a desire to belong to imagined communities based on cultural/racial/sexual sameness-for instance, as Korean or Japanese, as white or non-white, as homosexual or heterosexual, as man or woman, or (to be exceptionally specific) as a Korean Japanese woman with homosexual proclivities. In this sense, the subjects of identity in singular or plural terms are still distinguished one way or another by the politics of "either/or" rather than of "neither/nor." One good example of an "either/or" politics of identity would be the hyphenate mark that simultaneously includes and excludes a subject: "Korean Japanese" means neither Korean nor Japanese or either or both.

However, it may be time to consider the politics of "neither/nor" because the national boundary and its pre-given constitution of identity are being blurred and dismantled by the hybridization of culture in the process of globalization. If we imagine that identity breathes in the clear "pure" space of homogeneous culture, it may soon be suffocated as hybridized culture permeates the space. The ultimate logical result would be a total loss of sense of identity, which the film illustrates through the Japanese character Hoso (Yoshiki Arizono), the protagonist's friend who continually makes hilarious remarks such as "I like Chu-san [referring to the main protagonist, Tadao], but not Chosenjin. ${ }^{12}$ They are nasty, sly, and boorish. . . . Lend me some money." Residing in the third space that has displaced the homogeneity of Japan, Hoso is figuratively suffocated by the presence of competing identities in double-time: as the historical object dictated by "the pedagogical narrative of nation" (imposing the progressive, homogeneous, linear temporality and its pre-constituted national origin onto him), and as the subject defined by "the performative." This requires him to undo his former identity in coping with hybridized contemporaneity. Consequently, he winds up being disoriented in terms of his identity and his mental state and turns out to be literally schizophrenic.

On the other hand, the protagonist adopts "neither/nor" politics as he pronounces that his last name is "Ga" at the end of the film when he reunites with his Filipino girlfriend. His full Korean name is Chungnam Gang and the family name "Gang" is occasionally pronounced "Ga" by the Japanese due to their difficulty with Korean consonants. The significance of his rejection of both his "Gang" name as Korean as well as "Tadao," his Japanese appellation, would not be lost on both Koreans and Japanese who remain fully aware of their two nations' conflicted histories. Rather, he chooses "neither" name as he is "in-between" space as the Self/Other and Korean/Japanese, signifying the acceptance of a third identity by transcending the politics of difference. 
In terms of the third implication, translation affirms the subversive nature of the third space in postcolonial politics. Bhabha sees the process of translation as a sort of "disjunctive rewriting" (Location of Culture 226) that decenters the homogeneous space and continuous time of imperial power. In this way, the colonized subjects can restore and rebuild their subjectivity by translating imperialist language into their own cultural context. As such, we can see how such translation is actualized in the following conversation (conducted mainly in Japanese and translated to English by the present author) between the mother of the protagonist (whom they address as "mama-san" or madam) and her employees:

MAMA: Now that you are in Japan, you must act like the Japanese. Connie, translate!

CONNIE (in Tagalog): She said we should behave like the Japanese.

IRENE (whispering, in Tagalog): But why? I'm a Filipino. I can't walk bow-legged like them. [Giggles and high-fives with the other girls]

MAMA: Lolita, you better request your customers to buy you a drink. Use your charm. They will give you a drink since all Japanese are gentlemen. The more you get drinks from them, the more profit it will bring to the bar and the more your income will rise. Money is everything in this world. Connie, translate!

CONNIE: Mama, I am not your translator.

MAMA (ignoring the complaint): With money, you can build a house in your homeland and make your family happy. Connie? [After CONNIE ignores her] What I am saying is: don't lose your temper over the customers just because they grope you.

CONNIE (irritated): We only get paid for singing and drinking with guests, not from the kind of things you are asking us to do.

MAMA: Don't you forget that I am the one who promoted you as a manager.

CONNIE: Don't treat me as if I were a prostitute. I came to Japan when I was fifteen years old.

MAMA: I came here when I was ten! [Giggling occurs among the employees] I have more experience than any of you. I am your role model so if you listen to me and do what I am saying, it will make your life better. Connie, translate!

CONNIE (in Tagalog): She said her life was a series of miseries. If you don't follow her, then you will be happy.

As the dialogue informs us, the character Mama (Chungnam/Tadao's mother) tries to cajole her workers into working hard and getting more drinks even though it entails allowing the Japanese customers to sexualize their bodies. She further justifies her logic by saying that she has more experience than any of them and, therefore, knows how to make them wealthier and, by implication, happier. Rather 
than pay serious attention, Connie and the other employees laugh at her (one even cracks a racist joke), and Connie finally twists her employer's words into their opposite meaning.

Turning once more to Bhabha to see how translation resists hegemonic language and power, we realize how the voice of Mama articulates the interest of globalizing capitalism as she uses the promise of wealth and happiness to induce consent among her charges. However, for neo/colonized subjects such as Filipino workers, the promise is only a justification of the colonial project in the name of modernization and enlightenment as reflected in the history of the Philippines. Therefore, when the language of modern and capitalist hegemony-ironically coming also from the voice of the (formerly) colonized-is translated into a potentially exploitative context, it is only to be retranslated into a mockery as Connie points out: "If you don't follow her [the wannabe-colonizing power], then you [the colonized] will be happy."

Moreover, we can observe that the act of translation does not end with mocking the authority figure but goes further to displace the dynamics of the Subject/Other power relation. In the Hegelian view, the pronouncement of "I" is always exposed by desire (e.g., I am hungry), which is fulfilled through negation-either by destroying, transforming, and assimilating the desired object, the "non-I" (i.e., food is crushed and transformed into energy). In such a way, the reality of the desiring "I" is created and sustained only when its emptiness (endless desire) is filled by negating the external reality of the "non-I" (cf. Sarup 19-22).

The same mechanism is reflected in the relationship between Mama and Connie as the pronouncement of "I" dominantly resonates when Mama desires her subjects through negation. She wants to transform and assimilate Connie's reality into hers to fill her emptiness. To be more precise, she attempts to restore her denied identity as a colonized subaltern and as a second-class citizen in Japan by utilizing the logic of capital and profit. However, Connie, as the non-I, re-negates the negation rather than being consumed. She mocks Mama in her translation, and her denied reality is re-denied by her shared history. Subsequently, double negation becomes paradoxical displacement when Mama inadvertently places her desiring I "under erasure," which in turn makes her emptiness even more severe and her desire unfulfilled. In contrast, the desired "non-I" Connie fills her emptiness through the negation of the desiring I, which transforms her into a desiring I herself.

\section{The Hybridized Subaltern}

The dynamic between the desiring and the desired answers the very question raised earlier about the types of hybridized subalterns and the nature of their postcolonial resistance. As the study has demonstrated, the characters of Mama and Connie can be defined not only as the colonized diasporic subaltern in Japan but also as the hybridized agency in the third space. Rather than being assimilated 
and naturalized into Japanese homogeneous time and space, these hybridized subalterns remain stains against a mottled background-not only disrupting culture and identity but also threatening the temporal homogeneity of the colonial power. Nonetheless, a divergence between them in terms of their postcolonial resistance is discernible from their strategic use of mimicry, that is, either to mock (Connie) or to reinforce (Mama) the colonial vocabulary.

Mama uses mimicry to change her status from post-colonized victim to colonizing subject. Film texts offer a clear illustration of this since the director is able to literalize the Orientalistic consciousness resurfaced from the ideological confluence between global capitalism and nationalist politics. In Black Skin, White Masks, Fanon gave warning regarding the inferiority complex embedded in the mind of the black subject who tries to appropriate the traits of the colonizing power even though this appropriation becomes detrimental to the emancipation of the subject's own people. Although Bhabha claims that the imitation of the colonizer is mimicry and thus mockery (cf. in "Of Mimicry and Man: The Ambivalence of Colonial Discourse," Chapter 4 of Location of Culture 85-92), Fanon's point seems to be more persuasive if one were to look at the actual life circumstances of Koreans as reflected in the film-text.

In All Under the Moon, Fanon's black subject is arguably resurfaced in the guise of the Korean characters: the protagonist's mother, who reveals her prejudices against other foreigners by openly denouncing the Chinese as sly and cunning and Pinays as lazy and unproductive while idealizing Koreans as marriage candidates for her son; the Korean taxi company owner, who discriminates against the Iranian mechanic that would later be apprehended by the police due to his illegal residential status; and the other Korean taxi drivers, who refuse to take dark-skinned passengers, disparaging them as smelly individuals. Likewise, they partake in constructing the very same discriminative structure that had been used by the colonial power, which emphasized its enlightened culture, material accessibility, and racial superiority to justify its discriminatory policies against colonized nationals. In short, the director epitomizes the "imperialization of subject" among the colonized, in order to prove the colonizing society's subjectivity as a phallic center. This becomes even more intensified when coupled with the nativist discourse of nationalism. Mama's worry over her son's relationship with Connie, as a specific example, reveals her anxiety over racial impurity as dictated by primordial nativism as she responds "Go back to the Philippines!" when Connie asks her boyfriend (Mama's son) to go with her to her country in order to settle down together as husband and wife.

At this point, the ambivalence of mimicry between Mama and Connie portrayed by the film becomes more definite. Connie can be considered an "appropriate" hybridized subaltern in her mocking of the colonial law and language, which suggests the possibility of transformative postcolonial politics. However, the same mimicry becomes "inappropriate" and neocolonial when used by Mama (as well as the other Koreans) to legitimize and restore her subjectivity by differentiating 
herself from other subaltern groups like Pinays. In this sense, the Filipina subaltern, who was once deemed by Spivak as deprived of material accessibility and agency of enunciation, ironically "speaks" for herself. In contrast, Koreans become inappropriate hybridized subalterns by showing a more hybrid nature (hence, agency, according to Bhabha) due to their ability to merge global capitalist logic with nativist discourse. The Korean subalterns end up figuratively silencing their voice further as they give in to the oppressive structures (colonialism/capitalism/ nationalism) that constrain their freedom. They are paradoxically reincarnated as "pure" subalterns, ironically through an agency they claim from the benevolence of their former colonizers, the Japanese, who in turn may be seen as suffering from the East Asian equivalent of so-called white guilt (cf. Grzanka).

Perhaps the director speaks to/for the subaltern as a subaltern himself by maneuvering the rhetorical tactic of catachresis ${ }^{13}$ into his visualization. He turns the Zainichi in Japan into a representative of the colonial power (or more accurately, the reincarnation of a no-longer-existent colonial power), bound by its terms and vocabulary, despite the painfully obvious ironic fact that the nation they originated from was objectively and historically designated as Japan's longestheld colonial territory. In so doing, the film anticipates the imperialization of the subject alongside its concomitant imperialist enunciation, which the director had witnessed in his time outside his home. This constitutes a cautionary message for the contemporary Korean society that experiences the interstices of transnational/ ethnic/cultural hybridity.

\section{Conclusion}

The deliberations of the arguments that I have made so far constitute the bare bones of the interplay among nationalism, post/colonialism, and globalization in Korea. Focusing on the ways the image of Pinays interacting with Koreans has been constructed and consumed, I have shown a contradiction in the context of postcolonial politics among Koreans both within and outside Korea: in spite of its aim to break away from colonial legacies, the specifically Korean shape of postcolonial politics ironically participates in Orientalist/masculinist colonial strategies for the purpose of its own agenda, which is the restoration of national subjectivity.

This paper first sought to illustrate how various discourses, in conjunction with the postcolonial practice in Korea, construct the subaltern as a mere signifier without a signified through the Filipino mother from Wandeugi. The voice of the mother is translated, rearticulated, and eventually doubly effaced by the ideological and cultural filtering of the intellectual whose framework is one of nationalistic exclusion as Other and patriarchal inclusion as the apotheosis of femininity. In effect, the film conveys a positive answer to the question raised by Spivak in the case of Korean postcolonial gender politics because the film's construction of the 
subaltern's image is no different from the mechanics of the itinerary of silencing its subject.

In seeking to find the lost signified of the subaltern and its subversive potential for postcolonial politics, the study adopted the notion of hybridity and third space to show the ways in which the agency of the subaltern subverts and simultaneously reappropriates the authority of colonial power through a repurposed reading of All Under the Moon. Though the filmic concentration of the various hybridized symbols and signs serve to open up the third space and perturb the purportedly homogenized spatio-temporality of Japan, the study suggests that what transforms perturbation into either a subversive force against totalizing tendencies or an enforcer of the master narrative depends upon the strategic deployment of the nature of mimicry by the hybridized subaltern to either mock or reinforce the colonial vocabulary. The former was observed from the mimetic subversion of the "appropriate" hybridized subalternity in the Pinay heroine, Connie. The "inappropriate," as seen in the case of the Korean immigrant Mama, winds up with the subject being further silenced herself. If one's freedom is somebody's prison in the colonial narrative, the version of postcolonial politics narrated by Mama leads to her locking herself up in a prison whose boundaries are defined by the parameters set by the colonial episteme in the name of capital, progress, and nation, thereby paradoxically resulting in her reincarnation as the "pure" subaltern.

In this regard, the account of Mama and Connie proffered in All Under the Moon provides a template of the problematic situations against which we-asOthers must struggle and toward which we must continue to write the narrative of the "post"colonial endeavor. The tension between a postcolonial discourse that valorizes the nationalist/masculinist as an effective recuperation of cultural identity and a globalization that is reconfigured as the new order should not let us overlook the pitfalls set by meta-discursive regimes to interpellate their subjects. Thus, the subaltern cannot speak until a plethora of possible (even conflictive) meanings and multivalent differences are indubitably inculcated in postcolonial political activism. The realization for this vocation (that may be extended in real life such as the election in 2012 of the Wandeugi actress Jasmine Lee as the first naturalized citizen in the Korean National Assembly) would be the equivalent of a further unfolding of these stories in real historical time. 


\section{Notes}

The author wishes to acknowledge the invaluable help of Elizabeth Enriquez and Patrick Campos, professors at the University of the Philippines College of Mass Communication, for their invaluable suggestions for revisions of this paper. The author also would like to express a strong measure of gratefulness to the anonymous reviewers for the present journal who raised even more significant points.

1. Henceforth, the term "Korea" in this paper will refer to South Korea unless it becomes necessary to distinguish it from North Korea.

2. The term "compressed modernity" refers to the modernization process that occurred in Korea in an extremely condensed manner, which transformed the social, political, and economic structures of modern Korean society. Because of the resulting explosive rate of economic development, its sociocultural ramification is far-fetched. According to Chang. "the phenomena of intense competition, collision, disjointing, articulation, and compounding among traditional, modern, and postmodern elements ... or between foreign/ multinational/global elements and indigenous element within a compact sociohistorical context" (Chang, South Korea under Compressed Modernity 6-7).

3. Another noticeable ramification of compressed modernity was the "defamilialism" that gave rise to the emerging demographic issues in Korea, such as the aging population and low fertility rate. The country's extreme preoccupation with education and urbanization resulted in a labor shortage in $3 \mathrm{D}$ sectors (referring to dirty, dangerous, and difficult jobs) and difficulty in marriage for men in rural areas (Chang, "Individualization without Individualism" 23-39). In order to cope with the social problems, the bodies (and sexualities) of Third World women are in effect conscripted by this need for wives, entertainers, and factory workers even as the Philippines seeks to revive its moribund economy by relying on labor exportation.

4. In Lim's temporal critique, she conceptualizes immiscible times as a contestation of multiple temporalities that, by merging Bergsonism with postcolonial criticism, never dissolve into modern time consciousness. With this conception, she further illustrates how the discourse of homogeneous time sets aside "the marvelous" and imposes its linear, progressive, modernized conception to justify Western imperialist expansion: An anti-colonial critique of homogeneous time points out that the modern notion of progress and its corollary, the accusation of noncontemporaneousness, translate multiple ways of inhabiting the world into a single, homogeneous time. This translation is arguably a deliberate mistranslation in that the allochronic gesture-the appraisal of the other as an anachronism-served as a potent temporal justification for the colonial project. (83)

5. The term "worlding," which appears throughout Spivak's text, refers to the way in which Western textuality or writing during the colonial period serves as a rhetorical justification for colonial expansion by describing the global south as "uninscribed territory" awaiting civilization. According to Spivak, "as far as 
I understand it, the notion of textuality should be related to the notion of the worlding of a world on a supposedly uninscribed territory. When I say this, I am thinking basically about the imperialist project which had to assume that the earth that it territorialised was in fact previously uninscribed" (The Postcolonial Critic 1).

6. After the Spanish-American War in 1898, the US justified its aggression by describing the Filipino as either "half-devil or half-children" as white men's burden and by claiming that it was America's duty to enlighten this supposedly inferior race at any cost-even that of war (Jinhee Kim 38-39).

7. See "French Feminism in an International Frame" in which Spivak criticizes Julia Kristeva's About Chinese Women as an example of an accusation of the colonial benevolence of Western feminism.

8. This refers to a concept in film discourse derived from Foucault's explication of the author function in "What Is an Author?" wherein he asserted that the artwork, although created by an artist, is not the outcome of individual genius but a by-product of the social institution, ideological discourse, and formal convention in which the artist had identified.

9. Taken from the internet-based news article on her interview and translated by the present author. The source (dated 16 Nov. 2011) was retrieved from Jejusori.net on 15 March 2013 <http://www.jejusori.net/news/articleView. html?idxno $=106887>$.

10. After nearly forty years of seemingly prosperous but precarious economic growth in Korea, the world and its citizens were shocked in 1997 when then Korean president Kim Youngsam announced the need to seek the assistance of the International Monetary Fund (IMF). Labeled as a year of "national shame," 1997 was viewed by the citizens similar to the way they viewed the 1910 implementation of the Japan-Korea Annexation Treaty. The nation surrendered its economic autonomy by allowing the global surveillance system to reconstruct the local economic structure, necessitating a massive layoff of workers. The time was also considered a period of progress for gender politics in the familial sphere. The ensuing unemployment left men unable to support their family. Women saw increasing opportunities to enter what had been previously deemed as men's domain, the public sphere. Simply put, the gendered division of labor, "the husband as breadwinner and the wife as household manager," was fundamentally shaken (cf. Kim \& Finch). This resulted in a feeling of masculine loss in Korean society, which was bolstered by the emergence of a new family arrangement wherein the couple actively participates in household duties and financial contributions. Meanwhile, the neoliberalist, materialist, and knowledge-based economy, as an outcome of forced globalization after IMF policies, accelerated the rate of urban/rural polarization in Korea. This increased the number of unmarried farmers who became reliant on international marriages as the only way of forming a family, thus forming the majority of multicultural families in Korea. 
11. Although the film is fictional, the study defines it as semi-autobiographical since the director was a diasporic subject whose own experiences and feelings, inhabiting the liminal slipzones of culture, are infused in his work.

12. Chosenjin is a derogatory appellation referring to Koreans and is often used by and during the Japanese occupation in Korea.

13. Informed by Derrida's deconstructive reading of catachresis, which refers to "the original incompleteness or impropriety that is a general condition in all systems of meaning" (Morton 34), Spivak illustrated how the use of any "master word" (i.e., by the proletariat or women) tends to generalize and claim the representation of a group of people and their experience in spite of its arbitrary connection to its original referent and its meaning. With this use of catachresis, Spivak tactically explicates her reading of Charlotte Brontë's Jane Eyre by turning Bertha Mason, the mad wife of Rochester, into a representative of the colonized subaltern despite her origins as a member of the former slave-owning plantocracy (cf. Spivak, "Three Women's Texts" 244-45). Similarly, improper words are visualized as the imperialist vocabulary enunciated by the colonized Korean subaltern in the film.

\section{Works Cited}

Anderson, Benedict. Imagined Communities: Reflections on the Origin and Spread of Nationalism. London: Verso, 1991. Print.

Bhabha, Homi K. The Location of Culture. London: Routledge, 1994. Print.

--. Nation and Narration. London: Routledge, 1990. Print.

Chang Kyungsup. "Individualization without Individualism: Compressed Modernity and Obfuscated Family Crisis in East Asia." Journal of Intimate and Public Spheres 1 (2010): 23-39. Print.

--. South Korea under Compressed Modernity: Familial Political Economy in Transition. New York: Routledge, 2010. Print.

Chatterjee, Partha. The Nation and Its Fragments: Colonial and Postcolonial Histories. Princeton: Princeton UP, 1993. Print.

Cho Jinhui. "Representing Migrated Women in Korean Popular Films." Journalism \& Communication Studies 16.1 (2013): 379-404. Print.

Choi Chungmoo. "The Politics of Gender, Aestheticism and Cultural Nationalism in Sopyonje and the Genealogy." Im Kwom-Taek: The Making of a Korean National Cinema. Ed. David E. James and Kyung Hyun Kim. Detroit: Wayne State UP, 2001. 107-33. Print.

Choi Yangil, dir. See Sai Yôichi.

Deleuze, Gilles. Cinema 1: The Movement-Image. Trans. Hugh Tomlinson and Barbara Habberjam. Minneapolis: U of Minnesota P, 1986. Print.

Du Bois, W. E. B. The Souls of Black Folk. New York: Gramercy, 1994. Print.

Fanon, Frantz. Black Skin, White Masks. Trans. Richard Philcox. New York: Grove, 1952. Print. 
Foucault, Michel. "What Is an Author?" Language, Counter-Memory, Practice. Trans. Donald F. Bouchard and Sherry Simon. New York: Cornell UP, 1977. 124-27. Print. Grzanka, Patrick Ryan. White Guilt: Race, Gender, Sexuality and Emergent Racisms in the Contemporary United States. Dissertation, U of Maryland. Ann Arbor: ProQuest/ UMI, 2010.

Hardt, Michael, and Antonio Negri. Empire. Cambridge: Harvard UP, 20oo. Print.

"Hito: Firipinijin joyu Ruby Moreno-san" [People: Ms. Ruby Moreno, Filipina Actress]. Asahi Shinbun (4. Sept. 1996): 3. Print.

Hong, Jia. "The Multiculturalism of Korean Newspapers in the Gender Perspective: The Analysis of Kyunghyang, Dong-A, Chosun, Hankyoreh." Journal of Communication Science 10.4 (2010): 644-78. Print.

JanMohamed, Abdul R. "The Economy of Manichean Allegory: The Function of Racial Difference in Colonialist Literature." Critical Inquiry 12.1 (1985): 59-97. Print.

Joo Youshin. "Comments on Ideology of Nationalism and National Aesthetics of Im Kwon-taek's films-Centered on Chang (1997)." Daejung Seosa Yeong-gu 13 (2005): 63-88. Print.

Kim Jinhee. “The White Man's Burden: American Orientalism and the Formation of the American Identity in the Late 19th Century." Korean Society of American History 19 (2004): 23-49. Print.

Kim Seung-kyung and John Finch. "Living with Rhetoric, Living against Rhetoric: Korean Families and the IMF Economic Crisis." Korean Studies 26.1 (2002): 120-39. Print.

Kim Yeongsim. "Approach to or Deviation from the Korean Residents in Japan - with Emphasis on Where Does the Moon Rise in the Sky? and Family Cinema." The Korean Association of Literature and Film 1.2 (2000): 49-67. Print.

Klein, Christina. Cold War Orientalism. Berkeley: U of California P, 2003. Print.

Lee Dukwha. "Comparison Research between Works: Selected from A Prizer of Women Wave Literature published by Yeowon and works of women writers." The Society of Korean Fiction 37 (2008): 259-76. Print.

Lee Han, dir. Wandeugi. Scriptwriter Dong-Woo Kim. Perf. Yun-seok Kim, Ah-In Yoo, Su-young Park, Yeong-jae Kim, Sang-ho Kim, Hyo-ju Park, Jasmine Lee, Byeol Kang, Kil-Kang Ahn. UBU Film, 2011. Film.

Lim, Bliss Cua. Translating Time: Cinema, the Fantastic, and Temporal Critique. Durham: Duke UP, 2009. Print.

Loomba, Ania. Colonialism/Postcolonialism. 2nd ed. New York: Routledge, 2005. Print

--.. "Overworlding the Third World." 1991. Williams and Chrisman 305-23.

Morton, Stephen. Gayatri Chakravorty Spivak. New York: Routledge, 2003. Print. Routledge Critical Thinkers Series.

Parker, Andrew, Mary Russo, Doris Sommer, and Patricia Yaeger, eds. Nationalisms and Sexualities. New York: Routledge, 1992. Print.

Radhakrishnan, R. "Nationalism, Gender, and the Narrative of Identity." Nationalism and Sexualities. Eds. Parker et al. New York: Routledge,1992. Print.

Sai Yôichi (Choi, Yangil), dir. All Under the Moon. Scriptwriters Wui Sin Chong and Yôichi Sai. Perf. Gorô Kishitani, Ruby Moreno, Moeko Ezawa, Masato Furuoya, 
Yoshiki Arizono, Ken'ichi Endô, Masato Hagiwara, Akio Kaneda, Kumija Kim, Sujin Kim, Tatsuya Kimura, Jun Kunimura, Akaji Maro. Cine Qua Non, 1993. Film.

Said, Edward W. Orientalism. New York: Vintage, 1979. Print.

Sarup, Madan. An Introductory Guide to Post-Structuralism and Postmodernism. Athens: U of Georgia P, 1993. Print.

Schwarz, Henry, and Sangeeta Ray. A Companion to Postcolonial Studies. Malden: Blackwell, 2005. Print.

Spivak, Gayatri C. "Can the Subaltern Speak?" Williams and Chrisman 66-111.

--. "French Feminism in an International Frame." In Other Worlds. New York: Routledge, 1987. 136-41. Print.

--. The Post-Colonial Critic: Interviews, Strategies, Dialogues. Ed. Sarah Harasym. New York: Routledge, 1990. Print.

--.. "Three Women's Texts and a Critique of Imperialism." Critical Inquiry 12:1 (1985): 243-61. Print.

--.. "Woman in Difference: Mahasweta Devi's Douloti the Bountiful." Nationalisms and Sexualities. Eds. Andrew Parker et al. New York: Routledge, 1995. Print.

Suzuki, Nobue. "Between Two Shores: Transnational Projects and Filipina Wives in/ from Japan." Transcultural Japan: At the Borderlands of Race, Gender and Identity. Eds. David Blake Willis and Stephen Murphy-Shigematsu. New York: Routledge, 2008. 65-85. Print.

Williams, Patrick, and Laura Chrisman, eds. Colonial Discourse and Post-Colonial Theory: A Reader. New York: Columbia UP, 1994. Print.

Yang, Junghye. "Representation of Migrating Women: News Depiction of Inter-Racially Married Asian Women to Korean Men." The Journal of Media, Gender E Culture 7 (2007): 47-77. Print. 